\title{
INTERPRETING RADIOCARBON DATES USING EVIDENCE FROM TREE RINGS
}

\author{
Alex Bayliss \\ English Heritage, 23 Savile Row, London, W1S 2ET, United Kingdom. \\ Corresponding author. Email: alex.bayliss@english-heritage.org.uk. \\ Ian Tyers \\ Sheffield University, West Court, 2 Mappin Street, Sheffield, S1 4DT, United Kingdom. Email: i.tyers@sheffield.ac.uk.
}

\begin{abstract}
Often it is not possible to date a sample of wood from the final growth ring of the tree from which it came. In these cases, an "old-wood offset" is apparent. A number of quantitative approaches for the assessment of this offset are available, dependent on the actual tree rings that have been dated. A range of examples are given, demonstrating how such radiocarbon measurements can be interpreted using additional information from archaeology and dendrochronology.
\end{abstract}

\section{INTRODUCTION}

When dating wood or charcoal, it is frequently impossible to select samples from the final growth ring of the dated tree. The approach needed to estimate the date of this ring, and thus the felling of the tree from which it came, depend upon the number and nature of the rings between the radiocarbon sample and the edge of the tree. This paper demonstrates a number of these approaches. All have been implemented using OxCal v3.5 (Bronk Ramsey 1995, 1998, 2001) and the calibration data of Stuiver et al. (1998).

\section{'WIGGLE-MATCHING' TO BARK EDGE}

The simplest case is where we know the exact number of rings between each ${ }^{14} \mathrm{C}$ sample, and between the ${ }^{14} \mathrm{C}$ samples and the outside of the tree. An example of this situation is provided by waterlogged coffin F1790 from Barton upon Humber, Lincolnshire (Rodwell and Rodwell 1982). Two ${ }^{14} \mathrm{C}$ samples were processed from this coffin. Relating the core holes where these samples were taken to the subsequently constructed tree-ring sequence suggests that OxA-2283 (1300 $\pm 110 \mathrm{BP})$ consisted of a 30-yr block of rings, the center of which was $161 \mathrm{yr}$ earlier than OxA-2284 ( $915 \pm 80 \mathrm{BP}$ ). This also consisted of 30 rings, the center being 46 rings from the outside of the tree.

Using the D SEQ function of OxCal, a model which combines all this information suggests that coffin F1790 was constructed in cal AD 950-1210 (95\% probability; Figure 1). This is consistent with the tree-ring date for this coffin of winter AD 1131/2 (Figure 2).

The absolute dating of this sequence by dendrochronology suggests that OxA-2283 consisted of a 30-yr block centered on AD 924, and OxA-2284 of a 30-yr block centered on AD 1085. OxA2283 is statistically consistent with the weighted mean of the 3 decadal measurements spanning AD 910-40 from the calibration curve $\left(T^{\prime}=2.6 ; T^{\prime}[5 \%]=3.8 ; v=1\right.$; Ward and Wilson 1978), and OxA-2283 is consistent with the 3 measurements spanning $\mathrm{AD} 1070-1100\left(\mathrm{~T}^{\prime}=0.0 ; \mathrm{T}^{\prime}[5 \%]=3.8\right.$; $v=1)$. These measurements also show good overall agreement with the date suggested by dendrochronology ( $\mathrm{A}_{\text {overall }}=74.7 \%$; $\mathrm{An}=40.8 \%$; Bronk Ramsey 1995:429).

\section{SAMPLES ENDING IN THE HEARTWOOD/SAPWOOD BOUNDARY}

Another burial at Barton upon Humber, F3564, was placed in a coffin dug out of a single tree trunk. The ${ }^{14} \mathrm{C}$ sample, HAR-6501 ( $\left.900 \pm 70 \mathrm{BP}\right)$, consisted of a decadal block of wood ending in the heartwood/sapwood boundary. The best estimate for the date of this coffin is, therefore, the calibrated ${ }^{14} \mathrm{C}$

(C) 2004 by the Arizona Board of Regents on behalf of the University of Arizona Proceedings of the 18th International Radiocarbon Conference, edited by N Beavan Athfield and R J Sparks RADIOCARBON, Vol 46, Nr 2, 2004, p 957-964 


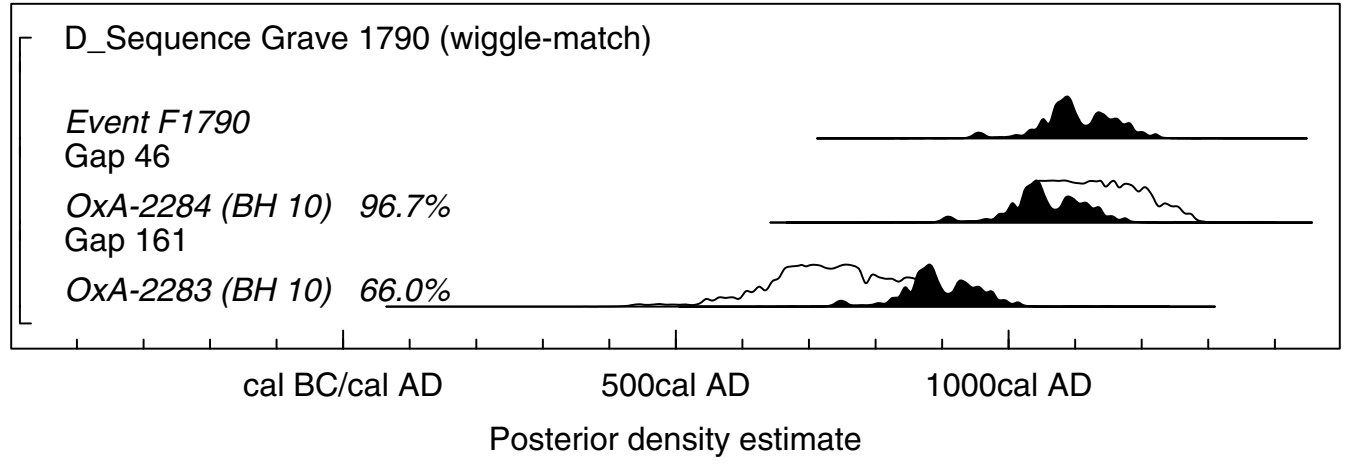

Figure 1 Probability distribution of dates from coffin F1790 at Barton upon Humber. Each distribution represents the relative probability that an event occurs at a particular time. For each ${ }^{14} \mathrm{C}$ date, 2 distributions have been plotted: one in outline which is the result of simple ${ }^{14} \mathrm{C}$ calibration, and a solid one based on the chronological model used. The large square brackets down the left-hand side and the OxCal keywords define the overall model exactly.

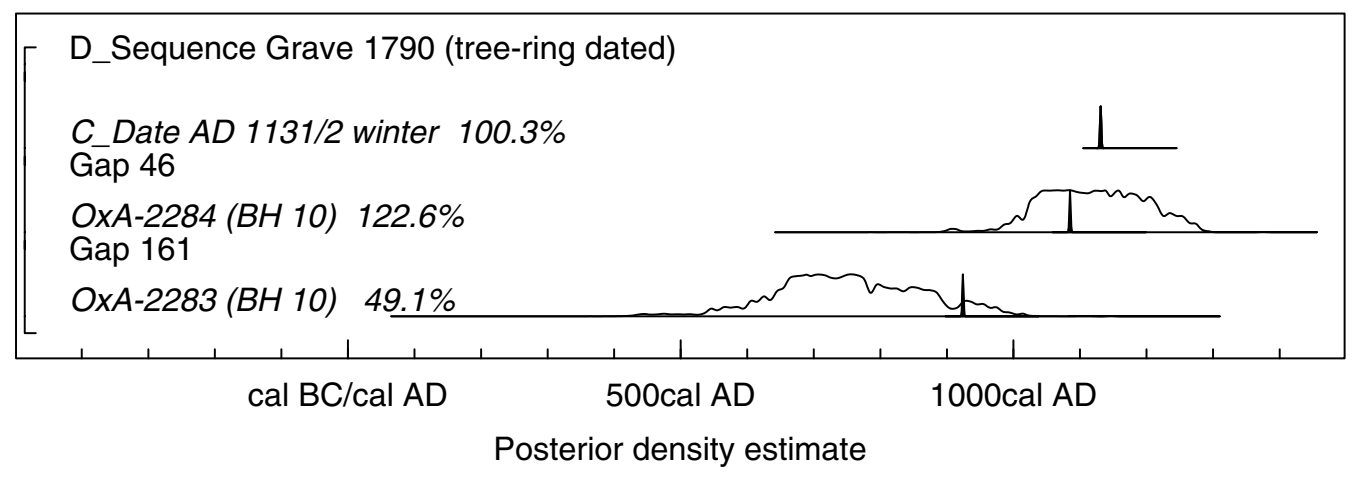

Figure 2 Probability distributions of dates from coffin F1790 at Barton upon Humber, including the absolute dating from dendrochronology (Tyers 2001).

date, offset by the distribution of the number of sapwood rings expected on oak timbers from England (Millard 2002).

This distribution is known empirically from dendrochronology (Figure 3; Table 1). The data set includes timbers from the prehistoric, Roman, medieval, and post-medieval periods (but not modern data), although it is dominated by material of Roman and medieval date. A national estimate has been used in this case because, although there is now some evidence for regionality within the medieval data set (Miles 1997), there is little evidence for this when considering multi-millennial data. In particular, at present there is insufficient data to construct specific sapwood estimates for other periods, and so it is not possible to determine whether there are appropriate regional divisions. Obviously, this position may change as further data are collected.

The sapwood estimate can be applied to the ${ }^{14} \mathrm{C}$ date using the PRIOR and SHIFT functions of OxCal (Figure 4). This model suggests that coffin F3564 dates to cal AD 1035-1290 (95\% probability).

The structure that implements this approach in OxCal is shown by the square brackets and keywords down the left-hand side of Figure 4. The sapwood estimate must be placed in a file $(* .14 \mathrm{~d})$ in the format shown in Table 1. This distribution is invoked as a prior distribution, and then used to shift a previously calibrated ${ }^{14} \mathrm{C}$ measurement. These functions must be used within a part of a model when MCMC is operational (if this is not the case, then the MCMC may be invoked using a "dummy" sequence, as shown in Figure 4). 


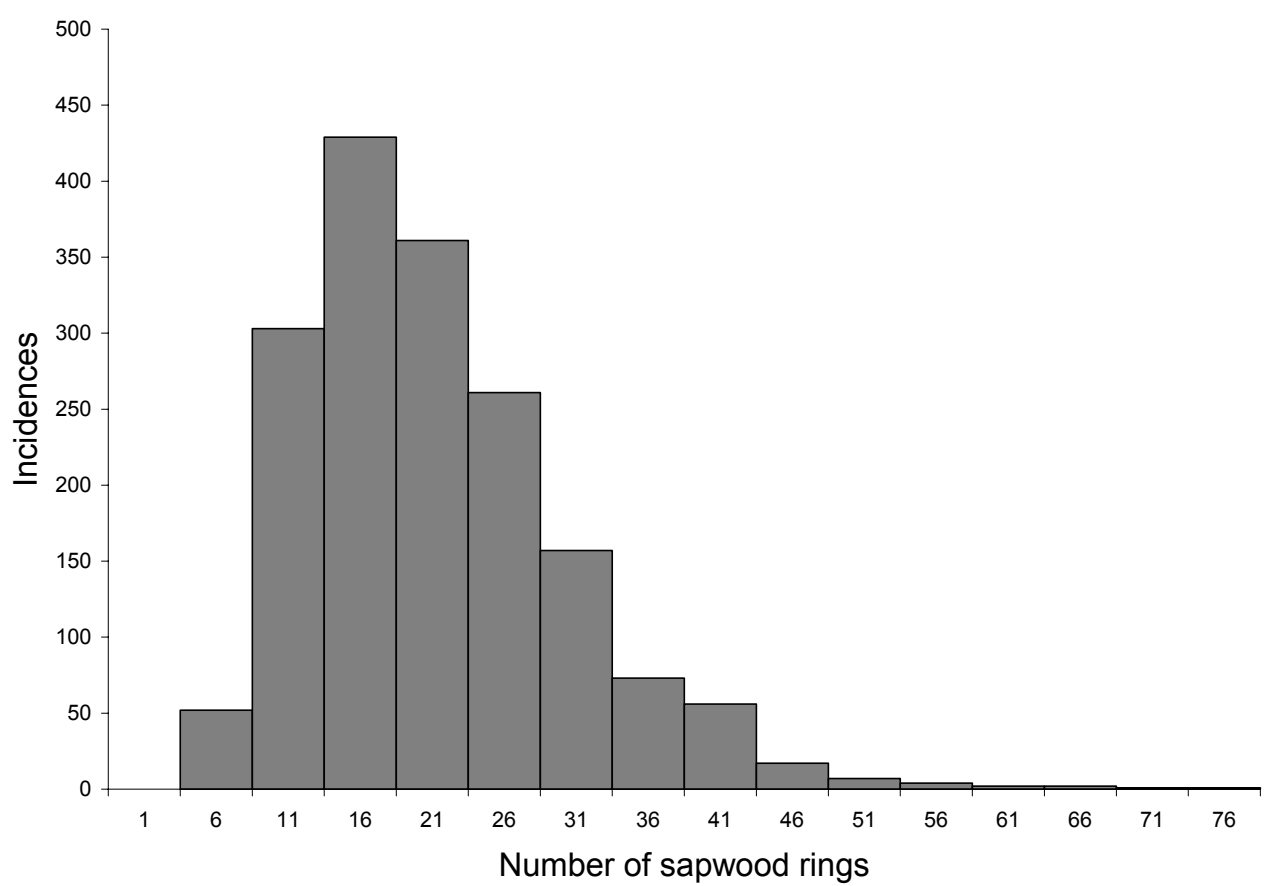

Figure 3 Distribution of the number of sapwood rings present on ancient oak timbers complete to bark edge from England.

Table 1 Distribution of the number of sapwood rings present on ancient timbers complete to bark edge from England, converted to an appropriate format for calculating offsets to calibrated ${ }^{14} \mathrm{C}$ dates in OxCal.

\begin{tabular}{lccc}
\hline $\begin{array}{l}\text { Number of } \\
\text { sapwood rings }\end{array}$ & $\begin{array}{l}\text { Occurrences } \\
(\mathrm{n}=1726)\end{array}$ & \multicolumn{2}{c}{ OxCal file (sapwood1.14d) } \\
\hline $1-5$ & 0 & 0 & 0.000000 \\
$6-10$ & 52 & 5 & 0.030127 \\
$11-15$ & 303 & 10 & 0.175550 \\
$16-20$ & 429 & 15 & 0.248552 \\
$21-25$ & 361 & 20 & 0.209154 \\
$26-30$ & 261 & 25 & 0.151217 \\
$31-35$ & 157 & 30 & 0.090962 \\
$36-40$ & 73 & 35 & 0.042294 \\
$41-45$ & 56 & 40 & 0.032445 \\
$46-50$ & 17 & 45 & 0.009849 \\
$51-55$ & 7 & 50 & 0.004056 \\
$56-60$ & 4 & 55 & 0.002317 \\
$61-65$ & 2 & 60 & 0.001159 \\
$66-70$ & 2 & 65 & 0.001159 \\
$71-75$ & 1 & 70 & 0.000579 \\
$76-80$ & 1 & 75 & 0.000579 \\
\hline
\end{tabular}




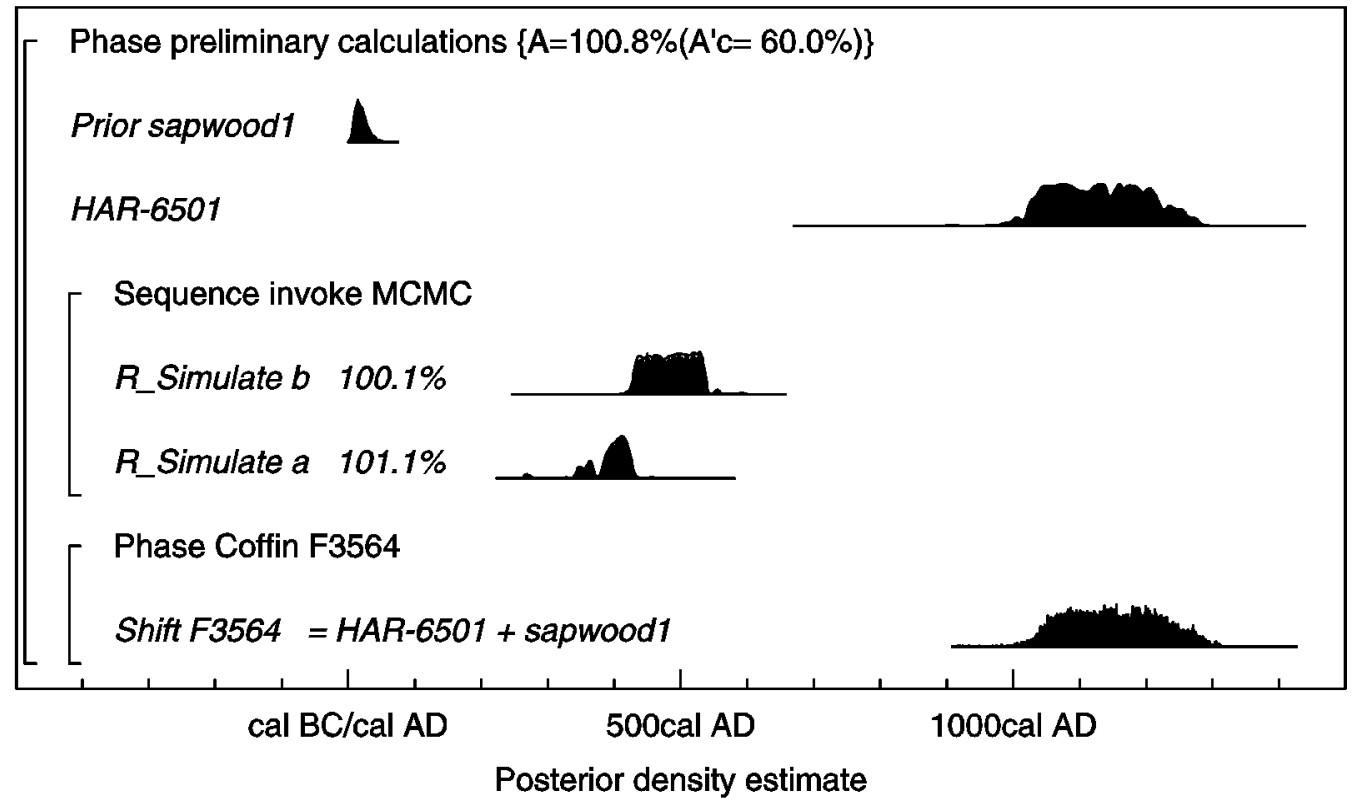

Figure 4 Probability distributions of dates from coffin F3564 at Barton upon Humber, shifting the calibrated ${ }^{14} \mathrm{C}$ date for the decadal sample to the heartwood/sapwood boundary by the expected number of sapwood rings for ancient oak samples in England (see Figure 3).

The skeleton buried within coffin F3564 produced a ${ }^{14} \mathrm{C}$ date of cal AD 1020-1160 (UB-4655; $957 \pm 17 \mathrm{BP})$.

\section{SAMPLES WITH SOME SAPWOOD}

Coffin F5045 at Barton upon Humber is another plank-built example. A single ${ }^{14} \mathrm{C}$ sample has been dated from this object (OxA-2286, $1035 \pm 80 \mathrm{BP}$ ), which consisted of a 40-yr block centered on $\mathrm{AD}$ 1015. This result is statistically consistent with the weighted mean of the 3 decadal measurements spanning AD 910-40 from the calibration curve $\left(T^{\prime}=2.6 ; T^{\prime}[5 \%]=3.8 ; v=1\right.$; Ward and Wilson 1978), and also shows good overall agreement with the date suggested by dendrochronology $\left(\mathrm{A}_{\text {overall }}=60.9 \% ; \mathrm{An}=50.0 \%\right.$; Bronk Ramsey 1995:429).

Absolute dating, however, is provided by dendrochronology. Another plank from this coffin has a heartwood/sapwood boundary dated to AD 1051 and 20 surviving sapwood rings (and, thus, a last dated ring of $\mathrm{AD}$ 1071). The best estimate for the date of this burial is provided, therefore, by the addition of a truncated sapwood distribution that accounts for the surviving sapwood rings (Figure 5; Table 2). This distribution is applied in a similar manner to previous examples (Figure 6) and suggests that this coffin was built in cal AD 1071-1095 (95\% probability).

\section{'WIGGLE-MATCHING' TO A HEARTWOOD/SAPWOOD BOUNDARY}

Figure 7 shows the results of the wiggle-matching of a floating tree-ring sequence from Swalecliffe, Kent (Masefield et al. 2003). Six sequential bi-decadal blocks of waterlogged wood were dated, ending $9 \mathrm{yr}$ before the heartwood/sapwood boundary on timber $5124.2<3>$. No sapwood survived on this sample, and so the best estimate for the date of this timber is provided by the wiggle-matched ${ }^{14} \mathrm{C}$ sequence offset by the expected number of sapwood rings (Figure 3 ).

This model suggests that the timber was cut in $730-680$ cal BC (95\% probability). 


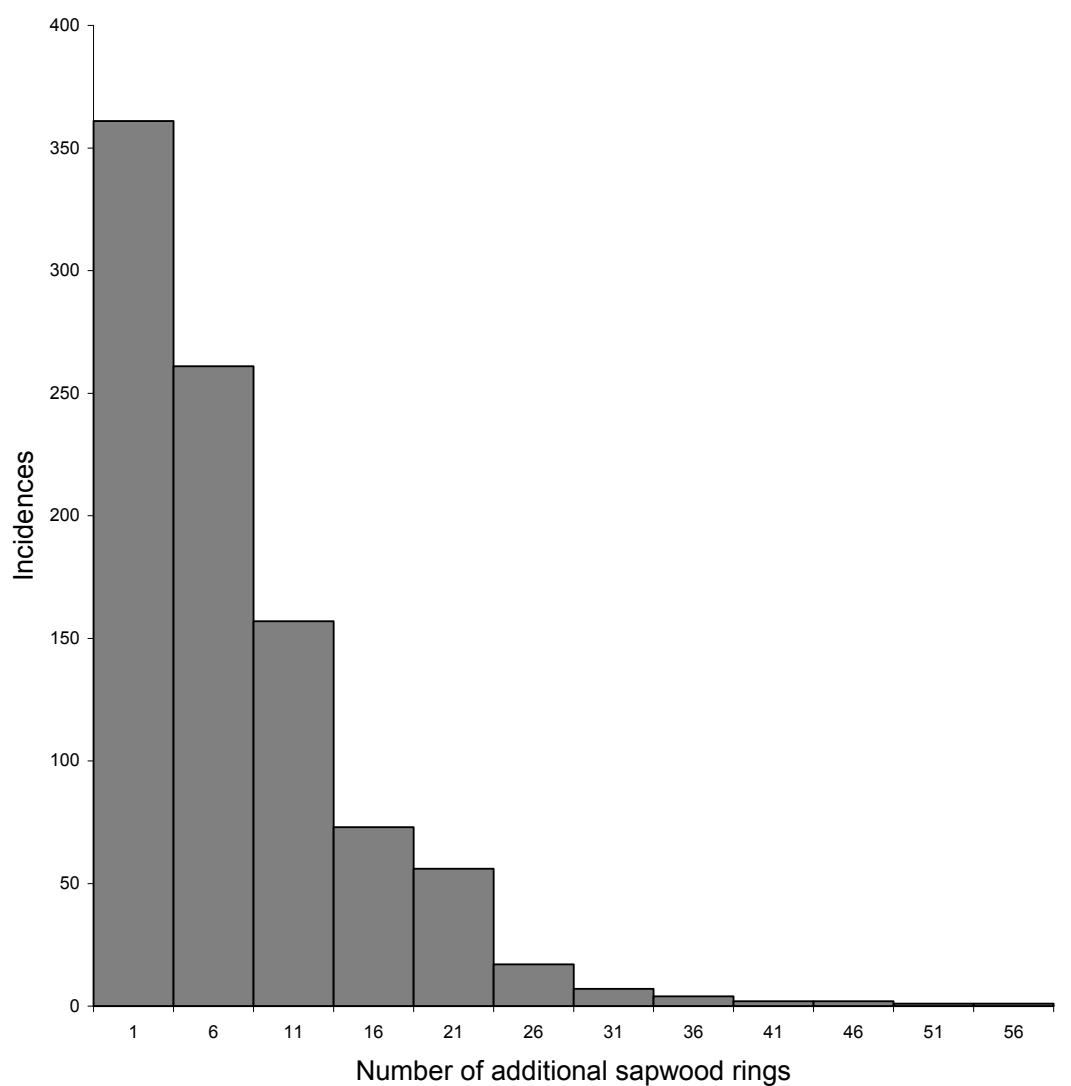

Figure 5 Additional number of sapwood rings expected on an oak sample with 20 surviving sapwood rings (based on Figure 3).

Table 2 Distribution of additional sapwood rings expected when 20 rings are present, converted to an appropriate format for calculating offsets to calibrated ${ }^{14} \mathrm{C}$ dates in $\mathrm{OxCal}$.

\begin{tabular}{llcr}
\hline $\begin{array}{l}\text { Number of additional } \\
\text { sapwood rings }\end{array}$ & $\begin{array}{l}\text { Occurrences } \\
(\mathrm{n}=942)\end{array}$ & \multicolumn{2}{c}{ OxCal file (sapwood1.14d) } \\
\hline $1-5$ & 361 & 0 & 0.383227 \\
$6-10$ & 261 & 5 & 0.277070 \\
$11-15$ & 157 & 10 & 0.166667 \\
$16-20$ & 73 & 15 & 0.077495 \\
$21-25$ & 56 & 20 & 0.059448 \\
$26-30$ & 17 & 25 & 0.018047 \\
$31-35$ & 7 & 30 & 0.007431 \\
$36-40$ & 4 & 35 & 0.004246 \\
$41-45$ & 2 & 40 & 0.002123 \\
$46-50$ & 2 & 45 & 0.002123 \\
$51-55$ & 1 & 50 & 0.001062 \\
$56-60$ & 1 & 55 & 0.001062 \\
\hline
\end{tabular}




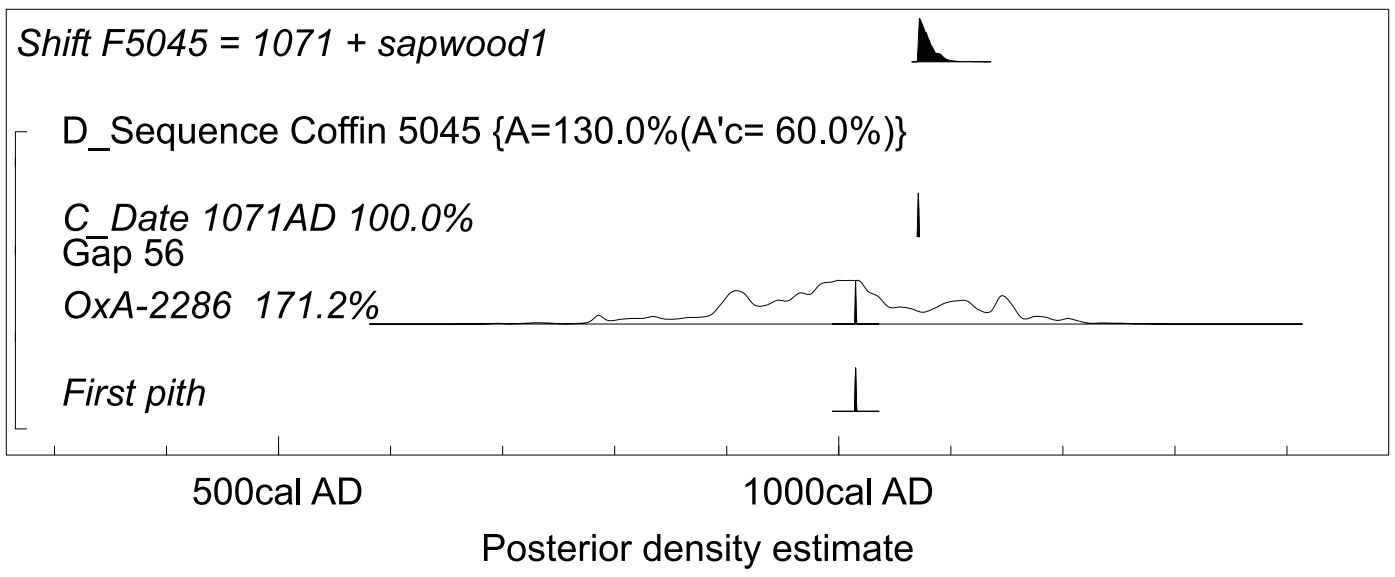

Figure 6 Probability distributions of dates from coffin F5045 at Barton upon Humber, incorporating the relative and absolute dating information known from dendrochronology and including the expected number of additional sapwood rings for ancient oak samples in England for timbers with this amount of sapwood survival (see Figure 5).

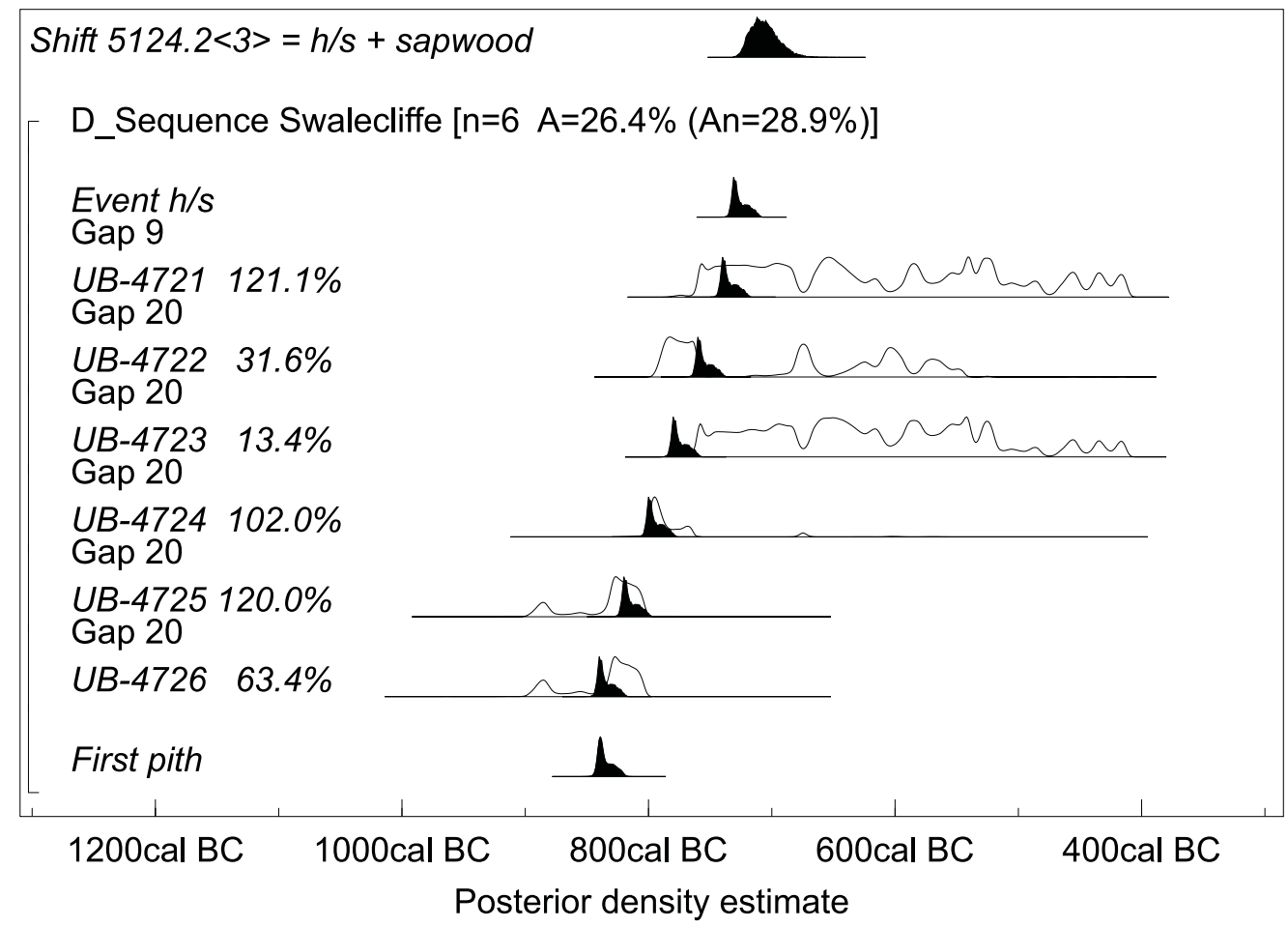

Figure 7 Probability distributions of wiggle-matched sequence from SWALCLF2, shifting the date for heartwood/sapwood boundary of sample $5124.2<3>$ by the expected number of sapwood rings for oak samples in England (see Figure 3 ).

\section{'WIGGLE-MATCHING' TO A TERMINUS POST QUEM}

A rather more complicated example is provided by the wiggle-matching of the timbers from the Dover boat (Bayliss et al. 2003). Here, a sequence of 5 contiguous bi-decadal samples was taken 
from a floating tree-ring sequence, with 34 rings to the last heartwood ring undated by ${ }^{14} \mathrm{C}$. Adding the probability distribution of the number of sapwood rings expected (Figure 3) provides a terminus post quem for the samples of short-lived material, which are those closest in date to the actual construction of the boat. These samples were of yew withies that tied the planking of the boat together, and moss which was used as caulking to make the craft watertight.

This model is shown in Figure 8. It suggests that the boat was constructed in 1640-1520 cal BC (87\% probability).

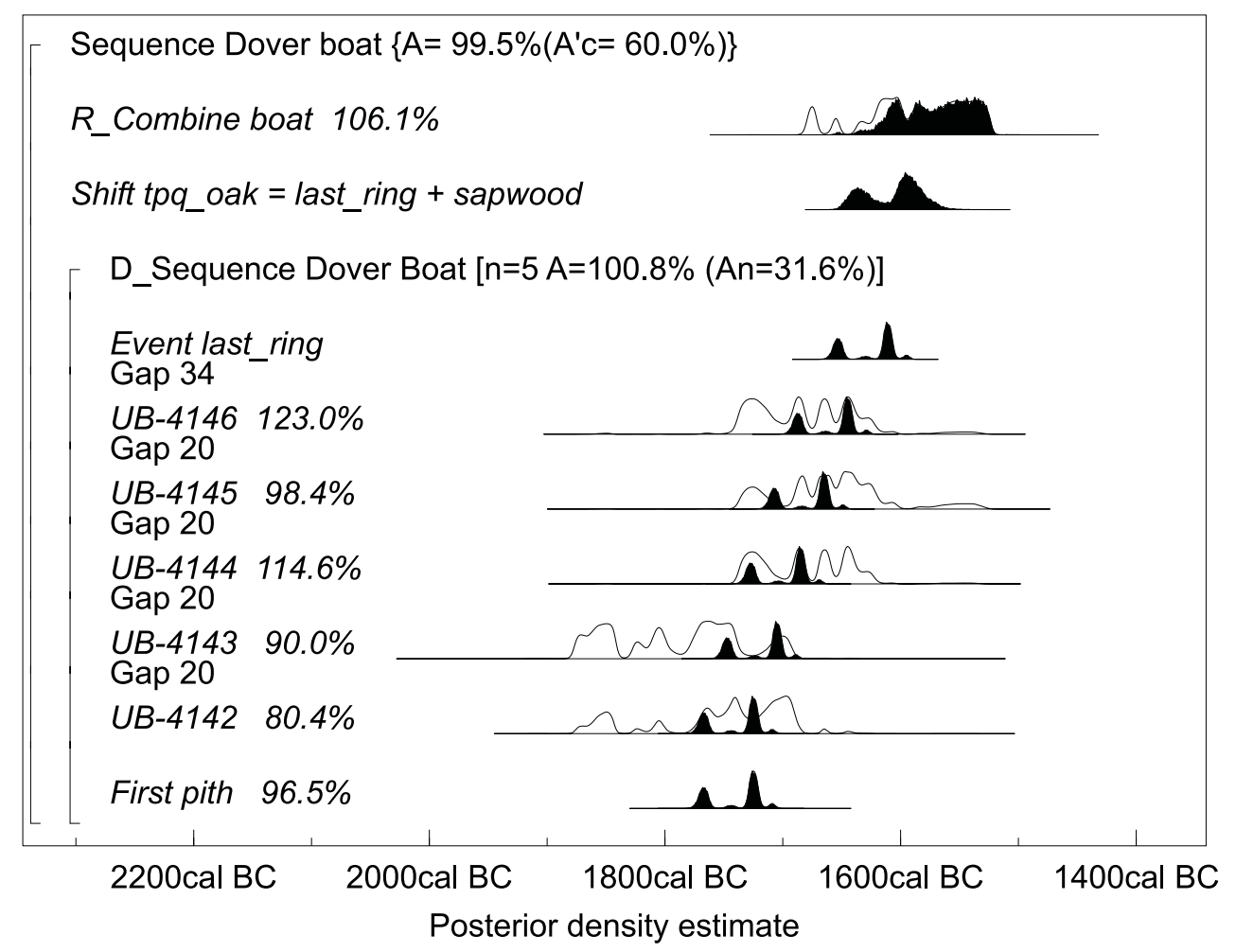

Figure 8 Probability distributions of wiggle-matched sequence from the Dover boat, shifting the date of the last heartwood ring by the expected number of sapwood rings for oak samples in England (see Figure 3). This provides a terminus post quem for the samples of short-lived yew withy and moss which were used to tie the boat together and keep it watertight.

\section{CONCLUSIONS}

Determining the age of the tree rings contained within a ${ }^{14} \mathrm{C}$ sample is crucial for its interpretation. Quantitative methods for correcting ${ }^{14} \mathrm{C}$ dates for a known or unknown "old-wood effect" have been suggested for many years (e.g. Warner 1990).

The Bayesian approach to interpreting chronological data allows the integration of ${ }^{14} \mathrm{C}$ dating with evidence from tree rings in a quantitative manner. This is particularly important in situations where precise and accurate chronology is required. 


\section{ACKNOWLEDGEMENTS}

We are grateful to Warwick Rodwell, the Canterbury Archaeological Trust, and RPS Group Plc. for permission to cite data in advance of full publication. English Heritage funded the ${ }^{14} \mathrm{C}$ dating reported here and the tree-ring analysis from Barton upon Humber. The tree-ring dating at Swalecliffe was funded by Southern Water. In addition, the excavation of the Dover Boat was supported by NorWest Holt and the Environment Agency, and that at Swalecliffe by Southern Water.

\section{REFERENCES}

Bayliss A, Groves C, McCormac FG, Bronk Ramsey C, Baillie MGL, Brown D, Cook GT, Switsur RV. 2003. Dating. In: Clark P. The Dover Bronze Age Boat. English Heritage Archaeological Monograph. p 250-5.

Bronk Ramsey C. 1995. Radiocarbon calibration and analysis of stratigraphy. Radiocarbon 36(3):425-30.

Bronk Ramsey C. 1998. Probability and dating. Radiocarbon 40(1):461-74.

Bronk Ramsey C. 2001. Development of the radiocarbon calibration program OxCal. Radiocarbon 43(2A): $355-63$.

Masefield R, Branch N, Couldrey P, Goodburn D, Tyers I. 2003. A later Bronze Age well complex at Swalecliffe, Kent. The Antiquaries Journal 83:47-121.

Miles D. 1997. The interpretation, presentation and use of tree-ring dates. Vernacular Architecture 28:40-56.

Millard A. 2002. A Bayesian approach to sapwood estimates and felling dates in dendrochronology. Archaeometry 44:137-43.
Rodwell W, Rodwell K. 1982. St Peter's Church, Bartonupon-Humber: excavation and structural study 197881. The Antiquaries Journal 62:283-315.

Stuiver M, Reimer PJ, Bard E, Beck JW, Burr GS, Hughen KA, Kromer B, McCormac G, van der Plicht J, Spurk M. 1998. INTCAL98 radiocarbon age calibration, 24,000-0 cal BP. Radiocarbon 40(3):104183.

Tyers I. 2001. The tree-ring analysis of coffin timbers excavated at the church of St Peter, Barton upon Humber, North Lincolnshire. Centre for Archaeology Report 48/2001.

Ward GK, Wilson SR. 1978. Procedures for comparing and combining radiocarbon age determinations: a critique. Archaeometry 20:19-31.

Warner RB. 1990. A proposed adjustment for the "oldwood" effect. In: Mook WG, Waterbolk HT, editors. Proceedings of the Second International Symposium ${ }^{14} \mathrm{C}$ and Archaeology. PACT 29:159-72. 